\title{
Pengembangan Industri Maritim di Nusa Tenggara Barat (NTB): Peluang dan Tantangan
}

\author{
M. Firmansyah ${ }^{1)^{*}}$, Masrun ${ }^{2)}$, Busaini ${ }^{3)}$ \\ 1)2)3) Fakultas Ekonomi dan Bisnis, Universitas Mataram \\ *E-mail corresponding author: firmansyah.feb@unram.ac.id
}

Received: 10-10-2020;

Accepted: 27-02-2021;

Available online: 30-04-2021

Ecoplan Vol. 4 No. 1, April 2021, hlm $1-9$.

ISSN p: 2620-6102

e: $2615-5575$
Abstract - One of the West Nusa Tenggara Governor's (2018-2023

era) mission is to encourage industrialization. This research tries to provide answers related to opportunities in the fisheries sector for industrialization and its challenges. The study was conducted with a qualitative approach. Qualitative (primary) data was obtained by conducting interviews with several experts in marine and fisheries and through FGD with related agencies. In contrast, secondary data was obtained from the fishing and marine services of (DKP) NTB Province. The results showed that NTB's fisheries were still relatively large in production and the area of fish land (capture and cultivation). And also, Non-fish production is suitable to be used as the main source of industrialization. However, several obstacles that need to be addressed, such as low human resources, infrastructure, supervision, and law enforcement of illegal practices in fisheries, low fiscal support and coordination among stakeholders, have not been resolved. Data validity is needed to be related to fisheries aspects, cross-stockholder forums such as Maritim product investment forums consisting of government, academia, and the business world, and directing industrial development towards the industrial Maritim cluster (ICM).

Abstrak - Salah satu misi Gubernur Nusa Tenggara Barat (era 2018-2023) adalah mendorong industrialisasi. Sementara itu, perhatian terhadap sektor perikanan belum diberi porsi yang memadai untuk menjawab kebutuhan tersebut. Tujuan penelitian ini menjelaskan peluang pengembangan perikanan di NTB sebagai bahan baku industri. Penelitian dilakukan dengan metode kualitatif dengan melakukan wawancara terhadap ahli dibidang perikanan, terdiri dai akademisi dan dinas perikanan. Hasil penelitian menunjukkan potensi perikanan NTB masih relatif besar, baik dalam usaha tangkap (off shore) maupun budidaya. Beberapa kendala seperti sumber daya manusia (SDM) yang rendah, infrastruktur perikanan yang belum memadai, pengawasan dan penegakan hukum atas praktik ilegal fishing belum maksimal, dukungan fiskal yang rendah dan koordinasi di antara para pemangku kepentingan yang belum maksimal juga perlu diselesaikan. Pembangunan industri menuju klaster industri maritim (ICM) dapat disarankan untuk dibangun.

Kata Kunci: Industri Maritim, Perikanan dan Bahan Baku 


\section{PENDAHULUAN}

Lautan diyakini berperan penting menciptakan kekayaan dan kesejahteraan generasi sekarang dan mendatang, sehingga abad ke-21 dianggap eranya ekonomi kelautan (Kronfeld-goharani, 2018; Wang \& Wang, 2019). Pembangunan kelautan atau ekonomi biru (Fernández-macho et al., 2015) menyediakan ruang pengembangan ekonomi seperti perikanan, akuakultur, pembuatan kapal, pariwisata dan transportasi laut. Laut juga menjadi sumber energi terbarukan dan bioteknologi (Fernández-macho et al., 2015). Keterbatasan lahan darat menyebabkan banyak negara melihat laut sebagai sumber daya penting, untuk itu diperlukan kebijakan pengembangan kelautan serta upaya memperkuat regulasi di dalamnya (Wang and Wang, 2019).

Mengingat pentingnya industri kelautan, era 1990-an China mengembangkan visi ekonomi kelautan berbasis teknologi dan pengetahuan (Su and Yang, 2018). Sementara Indonesia sejak Orde Baru pembangunan infrastruktur lebih berorientasi darat, walau pasca reformasi 1998 pembangunan maritim mulai disiapkan (Wicaksana, 2017).

Luas laut Indonesia adalah 70 persen, namun kemiskinan masyarakat nelayan masih relatif tinggi (Retnowati, 2011; Fatmasari, 2016). Belum tergambar kebijakan efektif menjadikan maritim sebagai titik tumpu pembangunan nasional, khususnya dalam upaya pengentasan kemiskinan. Isu-isu kemaritiman terbaru yang ramai dibicarakan di ruang publik masih seputar tol laut, ekspor baby lobster, impor ikan, sementara nelayan dan berbagai masalahnya belum banyak diselesaikan. Salah satu jalan menuntaskan kemiskinan adalah dengan industrialisasi bidang maritim.

Provinsi Nusa Tenggara Barat (NTB), oleh Gubernur terpilih periode 2018-2023 mencanangkan industrialisasi sebagai program utama. Sehingga, dalam Rencana Pembangunan Jangka Menengah Daerah (RPJMD) 2018-2023, NTB memprioritaskan pembangunan beberapa kawasan industri, antara lain Global Hub Kayangan Lombok Utara, Kawasan SAMOTA (Teluk Saleh, Pulau Moyo dan Gunung Tambora), Kawasan Industri Pariwisata Mandalika dan Kawasan Industri Smelter di Sumbawa Barat.

Dari semua kawasan tersebut, ada 2 industri di aspek maritim yaitu pengembangan teluk saleh dan industri pariwisata super prioritas nasional di kawasan Mandalika Lombok. Dari dua kawasan maritim dalam RPJMD tersebut, pengembangan Teluk Saleh yang dirancang untuk pengolahan hasil laut. Secara keseluruhan pengembangan perikanan tentu tidak hanya di Teluk Saleh, karena potensi laut NTB yang relatif besar.

Dibutuhkan manajemen bisnis yang baik untuk menyiapkan industri maritim tersebut (Chen et al., 2000). Langkah awal penyiapan tentu dengan mengidentifikasi potensi dan berbagai tantangan yang dihadapi. Sehingga, tujuan dari penelitian ini adalah mengkaji peluang dan tantangan pengembangan industri maritim di NTB.

\section{METODE PENELITIAN}

Penelitian dilakukan dengan pendekatan kualitatif. Tujuan penelitian kualitatif adalah mendeskripsikan dan memaknai (Vanderstoep and Johnston, 2009) fenomena atau kejadian serta melakukan interpretasi berdasar kejadian yang diamati. Data kualitatif diperoleh dari hasil wawancara terhadap beberapa partisipan (informan) yang terdiri dari pegawai dinas perikanan, akademisi dan pelaku bisnis. Adapun deskripsi informan: informan_1 berinisial Ir. P, MM akademisi, Informan_2 berinisial NK, SPi, M.Si birokrat, Informan_3: DM, MSc birokrat dan Informan_3 Dr. SH, M,Si sebagai akademisi. Di samping data kualitatif, penelitian ini juga menyajikan data sekunder sebagai pelengkap analisis berupa data produksi perikanan, potensi dan pemanfaatan perikanan provinsi NTB yang diperoleh di Dinas Kelautan dan Perikanan Provinsi NTB.

\section{HASIL DAN PEMBAHASAN}

\section{Maritim dan Pembangunan Ekonomi}

Industrialisasi merupakan proses perubahan (shifting) aktivitas ekonomi dari sektor pertanian (agraris) menjadi sektor industri, atau berbasis agraris dan kerajinan tangan digantikan industri yang berbasis mesin (Pula, 2017). Walaupun masih diperdebatkan, industrialisasi diyakini pertama kali terjadi di Inggris pada akhir abad ke-17 dengan beberapa faktor pendorong antara lain liberalisasi, pasar yang semakin kompetitif, kewirausahaan, fenomena alam dan dorongan menuju teknologi dan inovasi (Pula, 2017).

Dalam pembangunan industrialisasi, terdapat beberapa unsur dalam mengukur indeks kinerja industri yang harus dipenuhi, terdiri dari (Setiawati and Nachrowi, 2012: output, faktor produksi dan biaya produksi. Output terdiri dari nilai tambah dan pertumbuhannya, upah dan pertumbuhannya, jumlah perusahaan dan pertumbuhannya. Dari aspek faktor produksi terdiri dari jumlah tenaga kerja, barang 
modal, dan kemajuan teknologi. Sedangkan dari aspek biaya produksi terdiri dari produktivitas tenaga kerja, barang modal dan efisiensi (Setiawati and Nachrowi, 2012). Kombinasi dari output dan biaya, maka roh industrialisasi adalah efisiensi, keunggulan (kompetitif) tidak saja dari kualitas namun juga harga serta komitmen politik pemerintah (Storm, 2017).

Pentingnya industri dalam wilayah laut perspektif teori ekonomi bukanlah hal baru, abad ke-18 Adam Smith telah menggambarkan keuntungan ekonomi dari keberadaan transportasi laut (Stopford 2009). Smith baru menyentuh aspek distribusi, padahal dalam konteks produksi laut (bahari) tentu menjanjikan banyak bisnis yang dapat dikembangkan, seperti (Retnowati, 2011): Perikanan (tangkap dan budidaya), pengolahan hasil budidaya, industri bioteknologi, industri tambang dan energi, pariwisata bahari, penyediaan transportasi laut, penyediaan jasa maritim, pemanfaatan pulau-pulau kecil untuk pariwisata, penggunaan sumber daya non-konvensional, pengembangan kultur dan budaya bari dan bisnis terkait jasa lingkungan (konversi dan biodiversitas).

Banyak determinasi bisnis sektor kelautan yang dapat dikembangkan. Oleh karena itu, penting bagi negara dan daerah membangun sektor kelautan khususnya dalam mengatasi persoalan yang masih dihadapi, yaitu kemiskinan. Hasil studi menunjukkan, bisnis akuakultur di Asia mampu meningkatkan ketahanan pangan, pengentasan kemiskinan, inklusi sosial, pertumbuhan ekonomi berkelanjutan dengan tetap mempertahankan ekosistem bumi (Pomeroy et al., 2017; Kronfeld-goharani, 2018).

Dengan luasnya dampak ekonomi bisnis maritim, tentu diperlukan perencanaan bisnis yang efektif. Dalam mengembangkan bisnis maritim, tidak lepas dari empat rantai bisnis beserta turunannya, yaitu aspek produksi, distribusi, komersialisasi dan pasar (Firmansyah, 2016). Walaupun pembangunan industri memasuki generasi ke-4 atau biasa dikenal 4.0 namun secara prinsip sebenarnya tidak jauh dari penataan produksi, distribusi, komersialisasi dan pasar. Persaingan industri generasi terbaru hanya lebih jauh dalam akses pasar dan upaya mengurangi hambatan perdagangan (Stimson, Stough, \& Roberts 2002).

Di tengah kemajuan teknologi informasi (4.0) yang kian masif ditandai lahirnya bisnis unicorn, pembangunan nasional masih saja berorientasi darat. Pengabaian pembangunan maritim kurang sejalan dengan jati diri bangsa yang secara geografis berbentuk kepulauan (Dahuri, 2016). Kemajuan bidang maritim tidak berarti membatasi ruang gerak bisnis darat. Kemajuan sistem logistik justru meningkatkan efisiensi bisnis darat karena biaya transportasi yang lebih efisien. Indonesia merupakan negara yang paling mahal biaya logistiknya, yaitu diperkirakan 24 persen dari PDB, sedangkan negara lain umumnya di bawah 10 persen dari PDB (Dahuri, 2016).

Dinamika bisnis sektor maritim akan sejalan dengan perkembangan bisnis secara umum, bahkan ekonomi maritim mampu menjadi menyanggah perkembangan bisnis global dan perdagangan global (Chen et al., 2000). Dibutuhkan beberapa instrumen untuk mendorong bisnis maritim maju. Keterampilan kerja seperti komunikasi, teknik penyelesaian masalah, kemampuan beradaptasi, manajemen diri, kerja tim serta literasi dan teknologi digital (Chen et al., 2000) perlu diperkuat.

Di samping itu, aspek keberlanjutan (sustainable) merupakan hal penting lain untuk dipertimbangkan. Salah satu aspek penentu keberlanjutan adalah dengan menjadikan kultur atau nilai-nilai lokal yang berkembang dalam masyarakat sebagai instrumen untuk menjaga kelestarian laut dan ekosistemnya.

\section{Aspek Perencanaan Sektor Maritim}

UU No. 31 tahun 2004 mengatur tata kelola maritim, atau spesifiknya perikanan. Undang-undang ini mengatur pengelolaan ikan dan ekosistemnya, penangkapan, konservasi, nelayan, korporasi, pelabuhan dan seterusnya. Tujuan yang ingin dicapai dari keberadaan UU ini mulai dari meningkatkan taraf hidup, peningkatan devisa, kesempatan kerja, pemenuhan kebutuhan gizi, nilai tambah dan daya saing, industrialisasi dan juga sustainability (Puspitasari, Soemarmi and Juliani, 2016).

Payung hukum pengembangan industri manufaktur cukup rinci, pemerintah daerah hanya perlu menyusun road map dan rencana yang tepat untuk mencapai industrialisasi. Perencanaan bisnis maritim dalam konteks ini dengan merencanakan tiap-tiap tahapan bisnis yang akan dilewati sektor bisnis. Tahapan itu, dengan mengikuti alur value chains bisnis. Secara umum value chains terdiri dari input, produksi, distribusi, pemasaran dan pasar. Sebagai contoh tergambar proses value chains ikan lele dan ular di Kamboja berdasar hasil studi Pomeroy et al (2017). Di mana, rantai nilai dimulai dari (Pomeroy et al., 2017):

1. Input, di situ ada akifitas pasokan benih, pakan dan juga tersedia dokter hewan.

2. Produksi, hasil produksi (bahan baku) tersebar dalam 43,8 persen ke pengepul dan pedagang kecil, 37,5 persen masuk ke wholesale-buyer sisanya langsung ke pasar. 
3. Pengepul, hasil pengepul terinci ke dalam 10, 4 persen langsung ke pasar, 15,9 persen masuk ke processing (pengolahan) dan 17, 5 persen masuk ke wholesale-buyer.

4. Prosesing, hasilnya 41,1 persen masuk ke wholesaler sisanya langsung ke pasar.

5. Perdagangan, di sana ada aktivitas wholesaler dan supermarket yang menyediakan kebutuhan pasar domestik, Konsumsi, dalam aspek ini produk mencakup kebutuhan pasar domestik (Pomeroy et al, 2017.

Studi terkait value chains juga dilakukan di Indonesia, komoditas yang diteliti adalah ikan bandeng. Ada beberapa hasil dari pengolahan ikan bandeng yaitu Abon, kerupuk, otak-otak, bandeng presto, bandeng beku (Pomeroy et al., 2017).

Otonomi maritim dapat dilakukan dengan memperkuat kapasitas internal pelaku usaha, di antaranya menurut David (2011) dengan cara merencanakan SDM, pemasaran, aspek produksi dan juga keuangan (Benyamin, 2013). Porter merinci beberapa tahapan strategis untuk mengembangkan bisnis yang juga perlu dipersiapkan yaitu persaingan antar pengusaha (dalam konteks daerah, persaingan antar daerah) merebut pasar, peluang masuknya pemain baru pada usaha yang sama, jenis produk substitusi, kekuatan pemasok sebagai penentu intensitas produksi dan kekuatan atau psikologi konsumen (Benyamin, 2013).

\section{Kapasitas Produksi Bahan Baku}

Pada 2017 Provinsi NTB memiliki jumlah nelayan di laut dan perairan umum sebanyak 68.240 orang, jumlah kapal sebanyak 24.707 unit (DKP Prov NTB 2018). Bila dibuat angka rasio maka satu kapal digunakan 3 orang nelayan. Jumlah ikan yang dihasilkan mencapai 182.992 ton ikan, terdiri dari 179.134 ton di laut dan 3854 ton di perairan umum. Bila dibuat rasio satu kapal menghasilkan sekitar 7,4 ton per tahun, atau 0,6 ton per bulan. Dari angka tersebut tentu masih jauh dari kapasitas memadai. Dalam meningkatkan produksi sektor maritim sebagai bahan baku, perlu direvitalisasi setidaknya tiga aspek, yaitu: penangkapan, budidaya dan pengembangan non ikan.

Gambar 1. Pengembangan Produksi Kelautan

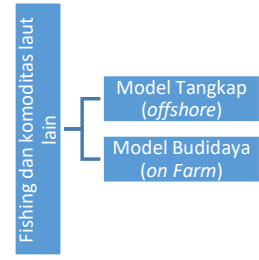

Semua ahli perikanan yang ditanya dalam penelitian ini apakah sektor maritim layak dijadikan sebagai bahan baku industri, mayoritas menyatakan layak. Pernyataan ahli tentu beralasan karena potensi hasil ikan dan non ikan yang relatif besar di NTB. Produksi ikan tangkap dan budidaya NTB dijelaskan sebagai berikut:

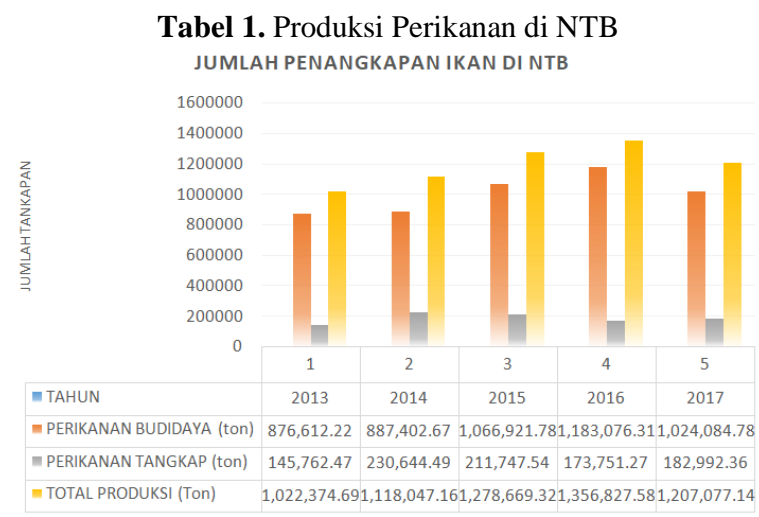

Sumber: DKP Provisi NTB, 2018

Dari tabel 1 menunjukkan, jumlah produksi perikanan tangkap jauh lebih kecil dari perikanan budidaya. Padahal berdasar rencana alokasi ruang laut berdasar dokumen RZWP3K NTB luas perikanan tangkap sebesar 2.384.459,59 hektar, sedangkan perikanan budidaya hanya seluas 72.863, 58 (DKP 
Provinsi NTB, 2018). Dari total produksi ikan, yang dimanfaatkan untuk pengolahan industri UMKM (Usaha Menengah Kecil Mikro) pada 2017 adalah sebesar 199.895 ton atau 0,017 persen saja. Jumlah UMKM yang mengelola perikanan sebagai produk industri 2017 adalah 2426 unit. Berdasar fakta tersebut, peluang untuk pengembangan industri berbasis produksi perikanan dalam skala yang lebih besar masih terbuka lebar.

Tabel 2. Data Potensi dan Tingkat Pemanfaatan Sumberdaya Ikan tangkap Pada WPP 573 dan WPP 713 Provinsi NTB

\begin{tabular}{|l|r|r|r|r|}
\hline \multirow{2}{*}{ Jenis ikan } & \multicolumn{2}{|c|}{ WPP $\mathbf{5 7 3}$} & \multicolumn{2}{c|}{ WPP 713 } \\
\cline { 2 - 5 } & $\begin{array}{c}\text { Potensi } \\
\text { (ton/tahun) }\end{array}$ & $\begin{array}{c}\text { Tingkat } \\
\text { Pemanfaatan } \\
\text { SDI (\%) }\end{array}$ & $\begin{array}{c}\text { Potensi } \\
\text { (ton/ tahun) }\end{array}$ & $\begin{array}{c}\text { Tingkat } \\
\text { Pemanfaatan SDI } \\
\text { (\%) }\end{array}$ \\
\hline Pelagis kecil & 294.092 & 0,91 & 104.546 & 0,61 \\
\hline Pelagis besar & 505.942 & 0,78 & 419.342 & 0,86 \\
\hline Ikan demersal & 103.501 & 0,96 & 77.238 & 1,04 \\
\hline Ikan karang & 8.778 & 1,36 & 365.420 & 1,70 \\
\hline Udang panaeid & 6.854 & 1,36 & 37.268 & 1,40 \\
\hline Lobster & 844 & 0,54 & 1.020 & 1,59 \\
\hline Kepiting & 465 & 1,05 & 5.016 & 1,70 \\
\hline Rajungan & 659 & 0,64 & 6.740 & \\
\hline Cumi-cumi & 6.556 & 1,40 & 10.010 & 1.026 .599 \\
\hline \multicolumn{1}{|c|}{ Total } & $\mathbf{9 2 9 . 3 3 0}$ & & & \\
\hline Sumber: DKP Proving & & & & \\
\hline
\end{tabular}

Keterangan:

Sumber: DKP Provinsi NTB, 2018

- WPP 573 = Area tangkap sekitar perairan Samudra Hindia bagian Selatan Jawa hingga NTB, Laut Sawu dan Laut Timur Bagian Barat.

- WPP 713=Area tangkap meliputi perairan selat Makassar, Teluk Bone, laut Bali dan Flores

Selain produk ikan, NTB menjadi salah satu pemasok garam nasional, di samping itu memiliki potensi rumput laut, ubur-ubur dengan pangsa pasar ekspor yang cukup memadai, khususnya ke negara Cina. Masalahnya produk-produk non ikan seperti garam belum terkelola secara baik, salah satu masalahnya adalah tata niaga, seperti tingginya impor garam negara, kualitas garam yang rendah (kualitas KW-2 ke bawah) dan lain-lain.

Di samping garam, jumlah produksi rumput laut NTB pada 2017 adalah 68.240 ton. Produksi rumput laut mengalami pasang surut (fluktuatif), sehingga komersialisasi produk maritim perlu gencar dilakukan, sering kali produk lokal kalah bersaing karena masyarakat lokal sendiri tidak mengenal produk asli daerahnya, produk-produk itu jauh dari konsumen. Penggunaan produk asli daerah oleh masyarakat lokal belum banyak dilakukan. Komoditas garam misalnya, garam luar bermerek kapal api dan dolpin mendominasi baik untuk kebutuhan rumah tangga maupun rumah-rumah makan.

\section{Sumber Daya Fisik Dan Non Fisik}

Ada kesamaan dan perbedaan prioritas yang dibangun berdasar pandangan empat informan ahli terkait menjadikan industrialisasi maritim di NTB. Namun bila disimpulkan beberapa prioritas itu, terdiri dari aspek fisik antara lain: 1). Ketersediaan data valid terkait kapasitas perikanan NTB untuk kebutuhan riset dan perhitungan investasi, 2). Penguatan Modal bagi usaha perikanan 3). Infrastruktur dan fasilitas pendukung.

Provinsi NTB menyadari pentingnya data sebagai acuan Analisa pembangunan. Sehingga diluncurkan program NTB satu data. Dinas Kelautan dan Perikanan juga menyodorkan data dalam website NTB satu data. Namun demikian, data-data yang disodorkan harus dipastikan validitasnya sehingga menjadi acuan investor untuk melakukan perhitungan benefit-cost investasi perikanan.

Ada beberapa peluang investasi perikanan yang ditawarkan oleh Pemerintah Provinsi, yaitu (KKP, 2018): Produk pengolahan kelautan dan perikanan, pengembangan gudang beku (cold storage), investasi perikanan tangkap, pembangunan industri wisata bahari dan investasi perikanan budidaya. Pemerintah daerah-pun memberi insentif untuk kemudahan berinvestasi melalui Pergub No.10 Tahun 2016, selama perusahaan menyerap tenaga kerja lokal, alih teknologi, daya saing daerah dan seterusnya.

Dari aspek non-fisik menurut ahli, antara lain: 1) Menyediakan SDM kemaritiman yang menguasai teknologi penangkapan dan pemasaran produk. Hal ini penting mengingat sektor maritime adalah sektor yang padat karya dan padat pengetahuan (Chang and Zhang, 2018). 2). Law enforcement terhadap pelaku illegal fishing dan perilaku kriminal lain dalam kelautan, 3). Kemitraan dan koordinasi lintas stackholder yaitu lintas sektor, lintas wilayah dan lintas science.

Beberapa kendala yang masih dihadapi NTB dijelaskan oleh informan ahli berikut: 
"Kemiskinan, destruktif and illegal fishing, IUU Reported, koordinasi lintas stakeholders yang masih lemah, minimnya investasi, rendahnya penguasaan teknologi, lemahnya kapasitas sumber daya manusia di birokrasi, keberpihakan penganggaran di sektor maritim yang masih sangat minim, pengawasan dan law enforcement yang masih lemah, minimnya riset di sektor maritim, lemahnya penataan kelembagaan dan tata niaga" (Informan-4)

Provinsi NTB masih terkendala pada persoalan praktik ilegal di sektor perikanan. Di samping disebabkan oleh kemiskinan, juga minimnya pemahaman nelayan akan bahaya yang ditimbulkan dari praktik ilegal. Rendahnya pengawasan oleh pemangku kebijakan tentu menjadi alasan lain dari praktik ilegal di sektor perikanan.

Contoh praktik ilegal misalnya menangkap ikan dengan bom, padahal beberapa tahun sebelumnya telah terbentuk Satgas Pengawas penangkapan ikan (antara, 2017). Tentu saja persoalan illegal fishing tidak boleh ada lagi ke depan, karena tidak saja terkait sustainability bagi ekosistem ikan namun juga terkait kepastian hukum dalam pengembangan investasi perikanan. Illegal fishing juga menunjukan rendahnya koordinasi dan pengawasan masing-masing stackholder daerah.

Teknologi yang didorong untuk dikembangkan adalah teknologi berkaitan dengan peningkatan budidaya dan tangkap serta teknologi dalam pemasaran hasil ikan. Penggunaan teknologi dibutuhkan infrastruktur (alat) sekaligus keahlian nelayan. Sehingga, pelatihan dalam pembuatan teknologi canggih dalam usaha perikanan perlu dipikirkan diselenggarakan secara berkala. Pengelolaan pasar berbasis market place atau platform adalah keniscayaan di era industri 4.0. sehingga pasar perikanan dapat menjangkau secara luas.

\section{Riset Dan Pengembangan ( $R$ and $D)$}

Dalam rangka meningkatkan kualitas sumber daya manusia perikanan dan kelautan untuk mencapai industrialisasi salah satunya ditopang oleh perguruan tinggi. Di Provinsi NTB, ada dua kampus yang memiliki program studi perikanan yaitu, Universitas 45 dengan fakultas kelautan dan perikanan dan Universitas Mataram dengan fakultas pertanian, program studi budidaya perairan. Universitas Mataram awalnya berencana membuka fakultas kelautan dan perikanan namun terkendala moratorium pembukaan fakultas baru oleh pemerintah pusat.

Dengan demikian, riset dan pengembangan industri perikanan tentu menjadi terhambat bila tidak didukung sumber daya manusia yang memadai di bidang tersebut. Di samping itu, rendahnya kualitas dan kuantitas riset. Bila dilihat dari google scholar dapat diamati peta riset terkait perikanan dan kelautan di NTB, umumnya dilakukan oleh peneliti di luar NTB, misalnya dari KKP, BPPT dan IPB. Sementara kontribusi peneliti di NTB sendiri masih sangat terbatas.

Industrialisasi dibutuhkan laboratorium pengembangan yang setiap saat mengkaji aspek produksi perikanan dan kelautan, pemasaran sampai dengan pendampingan start-up usaha perikanan. Dengan demikian, fakultas Teknik industri perlu juga tersedia bagi daerah untuk mendukung industrialisasi perikanan.

\section{Dukungan Penganggaran (APBD)}

Dukungan penganggaran daerah terhadap pengembangan sektor perikanan dan kelautan menjadi penting dalam meletakan industrialisasi di sektor ini. Politik anggaran daerah dapat terlihat pada pembiayaan APBD 2019 untuk pengembangan usaha perikanan dan kelautan. Program pemberdayaan masyarakat pesisir terdiri dari beberapa kegiatan yaitu: 1). Pengembangan Usaha Masyarakat Pesisir dan pulau-pulau kecil dengan program Penguatan usaha budidaya perikanan, terdiri dari: Penguatan Usaha Perikanan Tangkap Penguatan, Usaha pengolahan dan pemasaran hasil perikanan. 2). Program Pengembangan Budidaya Perikanan: Pengelolaan dan Pengembangan Produksi Perikanan Budidaya, Pengelolaan dan Pemberdayaan Usaha Pembudidaya Ikan, Pengelolaan Sistem Pembenihan Ikan. 3). Program Pengembangan dan Pengelolaan Perikanan: Pengelolaan Pelabuhan Perikanan, Pengelolaan dan Pengembangan Unit Penangkapan Ikan dan Kenelayanan, Pengelolaan Sumber daya Ikan dan Pengendalian Penangkapan Ikan. 4). Program Optimalisasi Pengelolaan dan Pemasaran Produksi Perikanan: Pengembangan Pengolahan dan Jaminan Mutu Hasil Perikanan, Pengembangan Usaha dan Logistik Hasil Kelautan dan Perikanan, serta Penguatan dan Pengembangan Pemasaran Produk Kelautan dan Perikanan.

Di samping itu, ada Program pengelolaan Laut, Pesisir dan Pulau-Pulau Kecil terdiri dari beberapa kegiatan yaitu: Pengawasan dan Pengendalian Sumber daya Kelautan dan Perikanan, Pelestarian dan 
Pemulihan Sumber Daya Kelautan dan Perikanan, Penataan Ruang Laut dan Pengelolaan Perairan Pesisir dan Pulau-Pulau Kecil dan Balai Pengembangan Budidaya Perikanan Pantai Sekotong.

Bila di lihat dari postur APBD dapat dijelaskan bahwa upaya peningkatan kuantitas dan kualitas hasil laut sebagai bahan baku industri oleh Dinas Kelautan dan perikanan Provinsi NTB telah tepat sasaran. Hasil produksi tersebut dapat ditindaklanjuti oleh dinas perindustrian untuk penguatan aspek hilir (industri).

\section{Tata Niaga Bisnis}

Menurut informan-2 kendala lain selain anggaran yang relatif kecil adalah validitas data potensi dan pengawasan terhadap program yang lemah. Sehingga, program hanya sukses di awal namun tidak berkelanjutan. Secara lengkap, pemaparan informan 2 sebagai berikut:

"Belum tersedianya data potensi dengan baik. Kurangnya kerja sama antar stake holder. Pengawasan program kurang terlaksana dengan baik”(Informan-2)

Umumnya beberapa dinas yang menangani rantai industri dari hulu sampai hilir belum terkoordinasi dengan baik. Masing-masing dinas terkesan berjalan sendiri. Harusnya dalam konteks industrialisasi produk perikanan dan kelautan yang dikembankan dinas perikanan dan kelautan, perlu dijemput dinas perindustrian untuk dikembangkan sebagai bahan baku industri, dipasarkan atau dijual dinas perdagangan, dibantu dinas koperasi untuk membangun keuangan nelayan dan dibesarkan oleh dinas penamanan modal dan pelayanan satu pintu (DPMPT-SP) untuk investasinya.

Kerja sama yang kurang optimal tidak saja terjadi antar OPD (Organisasi Perangkat Daerah) namun juga dengan pihak swasta. Swasta yang paling mengerti seluk beluk industri dan bisnis di dalamnya. Dalam mempermudah upaya koordinasi antar stockholder informan-3 memberi solusi untuk dibentuk forum dari setiap komoditas. Forum ini melakukan pertemuan dan membahas secara tuntas terkait produksi dan pengembangan produk. Misalnya Fish Investment Forum (FIF), Rumput Laut Investment Forum (Rulif) atau Salt Investment Forum (SIF). Lebih jauh informan-3 menjelaskan sebagai berikut:

"perlu adanya forum di tiap komoditas yang fokus memikirkan dan melaksanakan kegiatan dalam rangka mempercepat komoditas menjadi sektor unggulan..."

Kementerian Kelautan dan Perikanan secara berkala menyelenggarakan Marine and Fisheries Business and Investment Forum dengan agenda percepatan bisnis dan investasi perikanan nasional. Hal yang sama perlu dilakukan Pemerintah Provinsi NTB. Targetnya, memperkenalkan potensi perikanan, menawarkan insentif bisnis dan menjelaskan lahan industri yang clear and clean untuk pembangunan pabrik dalam industri kelautan.

\section{Ekosistem Industri: Sebagai Tata Kelola}

Model budidaya dibutuhkan sumber daya nelayan yang memadai, teknologi, infrastruktur, kualitas pembibitan dan pendampingan. Budidaya diharapkan produksi ikan melimpah dan berkelanjutan, sehingga berpeluang untuk di bangun Maritim Industrial Cluster (MIC) berbasis usaha pengolahan ikan. MIC dianggap mampu menciptakan daya saing ekonomi dan persaingan global (Karahan and Kirval, 2018; Xiao and Wang, 2019), kluster dapat memfasilitasi berkembangnya industri 4.0 (Jankowska and Götz, 2017). Model pengembangan kluster industri secara umum berkembang di darat. Namun, berdasar beberapa kajian sebelumnya terbukti mampu dikembangkan dalam bisnis sektor maritim.

Pengolahan ikan dapat berupa industri pengalengan ikan dan pengolahan produk ikan ke dalam berbagai bentuk (determinasi). Di samping itu, untuk memenuhi kebutuhan pasar tertentu dapat pula dilakukan ekspor ikan mentah. Konsep kluster yang dikembangkan Porter misalnya mengumpulnya industri yang sejenis dalam satu kawasan atau secara konseptual sebagai konsentrasi geografis perusahaan yang saling berhubungan, di dalamnya ada pemasok, penyedia layanan, perusahaan industri terkait dan lembaga terkait dalam bidang tertentu (Djoumessi, Chen and Cahoon, 2019). Pengembangan kluster sangat mungkin dilakukan di NTB, karena memiliki beberapa teluk besar dan potensial, di antaranya Teluk Saleh, Teluk Bima dan Teluk Waworada. Beberapa teluk ini menghasilkan komoditas ikan seperti ikan kerapu, udang vaname, lobster, ubur-ubur dan seterusnya. 


\section{Dukungan Regulasi}

Perda No.12 tahun 2017 adalah berkaitan dengan "rencana zonasi wilayah pesisir dan pulau-pulau kecil provinsi Nusa Tenggara Barat tahun 2017-2037" Perda mengatur sustainability sektor perikanan sekaligus upaya meningkatkan produksi ikan. Secara rinci perda menjelaskan langkah-langkah perlindungan dan pengembangan ekonomi di sektor perikanan. Lebih jauh informan 3 menjelaskan sebagai berikut:

"Pengawasan dan pendampingan secara intensif terhadap pemanfaatan sumber daya kelautan perikanan, Peningkatan kapasitas SDM di level pemerintah dan masyarakat pelaku pemanfaatan sektor maritim (nelayan, pembudidaya, etc), Penataan kelembagaan sesuai kapabilitas, dukungan infrastruktur dan dukungan fiskal yang memadai bagi pengembangan sektor kemaritiman, penguatan jejaring dan kemitraan dengan privat sektor, perijinan yang tidak berbelit dan akuntabel, memperkuat koordinasi dan sinkronisasi program lintas sektor. Menjamin penerapan Perda no 12 tahun 2017 secara akuntabel dan transparan".

Dengan demikian, secara regulasi atau aspek aturan pengembangan sektor perikanan telah tersedia di NTB, tinggal implementasinya.

\section{KESIMPULAN}

Berdasar jumlah produksi dan luas lahan, Provinsi NTB layak menjadikan sektor perikanan sebagai dasar bahan baku industrialisasi. Secara regulasi telah tersedia payung hukum untuk memperkuat sektor perikanan sebagai sumber industrialisasi. Namun demikian, rendahnya SDM di sektor maritim, infrastruktur, pengawasan dan law inforcement terhadap praktik ilegal dalam sektor kelautan, dukungan fiskal yang masih rendah dan koordinasi antar stackholder masih menjadi kendala.

\section{IMPLIKASI KEBIJAKAN}

Mengingat peluang pengembangan sektor maritim masih cukup besar untuk kebutuhan industrialisasi, pemangku kepentingan perlu mengupayakan peningkatan produksi produk perikanan secara kuantitas dan kualitas. Beberapa upaya yang perlu dilakukan adalah 1). Menyiapkan penganggaran dan program yang memadai dalam memperkuat sektor kelautan, 3. Menyediakan data valid terkait aspek perikanan sebagai dasar analisis tata kelola, 2). Melahirkan forum bersama yang mendorong industrialisasi maritim, 3). Mengarahkan pembangunan industri ke arah industry cluster maritim (ICM).

\section{DAFTAR PUSTAKA}

Antara (2017) 'NTB bentuk satgas pengawas "illegal fishing", antara.com. Available at: https://www.antaranews.com/berita/647576/ntb-bentuk-satgas-pengawas-illegal-fishing.

Benyamin, P. (2013) 'Manajemen Dan Pengembangan Pemasaran Pada Perusahaan Perikanan Di Sidoarjo', AGORA, 1(1).

Chang, Y. and Zhang, X. (2018) 'Optimization of Continuing Education of Marine Human Resources in China Based on System Stability', Educational Sciences: Theory \& Practice, 18(5), pp. 2403-2409.

Chen, P. S.-L. et al. (2000) 'Employability skills of maritime business graduates: industry perspectives.', WMU Journal of Maritime Affairs, 17(2), pp. 267-292.

Dahuri, R. (2016) 'Ironi Ekonomi Dualistis', in Munir, B. (ed.) NTB Pusat Pangan Halal Dunia. Yogyakarta: Regional Institute 104, pp. 6-7.

Djoumessi, A., Chen, S. L. and Cahoon, S. (2019) 'Factors influencing innovation in maritime clusters: An empirical study from Australia', Marine Policy, (December 2018).

DKP Provinsi NTB, 2018. Potensi Usaha dan Peluang Investasi Kelautan dan Perikanan Provinsi NTB. Provinsi NTB

Fatmasari, D. (2016) 'Analisis Sosial Ekonomi dan Budaya Masyarakat Pesisir Desa Waruduwur, Kecamatan Mundu, Kabupaten Cirebon’, Al-Amwal, 6(1), pp. 144-166. 
Fernández-macho, J. et al. (2015) 'Measuring the maritime economy : Spain in the European Atlantic Arc', Marine Policy. Elsevier, 60, pp. 49-61.

Firmansyah, M. (2016) 'Bisnis Pangan Halal Beserta Turunannya: Peluang dan Tantangan', in Munir, B. (ed.) NTB Pusat Pangan Halal Dunia. Yogyakarta: Regional Institute 104, pp. 51-66.

Jankowska, B. and Götz, M. (2017) 'Clusters and Industry 4.0 - do they fit together?', European Planning Studies, 25(9), pp. 1633-1653.

Karahan, C. B. and Kirval, L. (2018) 'Clustering potential of Istanbul maritime sector Clustering potential of Istanbul maritime sector', Maritime Business Review, 3(3), pp. 314-336.

KKP (2018) Potensi Usaha dan Peluang Investasi Kelautan dan Perikanan Provinsi Nusa Tenggara Barat, Direktorat Jenderal Penguatan Daya Saing Produk Kelautan dan Perikanan: Kementerian Kelautan dan Perikanan. Available at: https://kkp.go.id/an-component/media/upload-gambarpendukung/A_PDS/Potensi Usaha dan Investasi/NTB.pdf.

Kronfeld-goharani, U. (2018) 'Maritime economy: Insights on corporate visions and strategies towards sustainability', Ocean and Coastal Management. Elsevier, 165(February), pp. 126-140.

Pomeroy, R. et al. (2017) 'Linkages and Trust in the Value Chain for Small-scale Aquaculture in Asia', Journal of the World Aquaculture Society, 48(4), pp. 542-554.

Pula, B. (2017) 'Industrialization and Deindustrialization', The Wiley-Blackwell Encyclopedia of Social Theory, (1962), pp. 1-3.

Puspitasari, N., Soemarmi, A. and Juliani, H. (2016) 'Fungsi Pelabuhan Perikanan Samudera Nizam Zachman Sebagai Sarana Pendukung Industri Perikanan Di Jakarta Utara', DIPONEGORO LAW JOURNAL, 5(4), pp. 1-17.

Retnowati, E. (2011) 'Nelayan Indonesia Dalam Pusaran Kemiskinan Struktural (Perspektif Sosial, Ekonomi, dan Hukum)', Perspektif, XVI(3), pp. 149-159.

Setiawati, D. and Nachrowi, N. D. (2012) 'Pembangunan Indeks Kinerja Industri Industrial Performance Index Development Pendahuluan Tinjauan Referensi', Jurnal Ekonomi dan Pembangunan Indonesia, 13(1), pp. 47-68.

Stopford, M. (2009) Maritme Economics. Third Edit. London and new york: Routledge.

Su, M. and Yang, Y. (2018) 'Evolution of district marine policies in China : The case of Shandong Province', Marine Policy. Elsevier Ltd, (December 2017), pp. 0-1.

Vanderstoep, S. W. and Johnston, D. D. (2009) Research Methods For Everydaya Life: Blending Qualitative and Quantitative Approaches. San Francisco: John Wiley \& Sons, Inc.

Wang, Y. and Wang, N. (2019) 'The role of the marine industry in China' s national economy : An input output analysis', Marine Policy. Elsevier Ltd, 99(October 2018), pp. 42-49.

Wicaksana, I. G. W. (2017) 'Indonesia's maritime connectivity development: Domestic and international challenges', Asian Journal of Political Science, 25(2), pp. 212-233.

Xiao, W. and Wang, L. (2019) 'The Identification of Maritime Industry Clusters Using Maritime Industry Super-network', Ekoloji, 28(107), pp. 2023-2029. 